\title{
Refractive Outcomes in Fuchs' Endothelial Corneal Dystrophy: Conventional and Femtosecond Laser-Assisted Cataract Surgery
}

\section{Ellen $\mathrm{H}$ Koo \\ Vikram Paranjpe (D) \\ William J Feuer \\ Patrice J Persad (D) \\ Kendall E Donaldson}

Bascom Palmer Eye Institute,

Department of Ophthalmology, Miller

School of Medicine at the University of

Miami, Miami, FL, USA
Correspondence: Ellen H Koo Bascom Palmer Eye Institute, Department of Ophthalmology, Miller School of Medicine at the University of Miami, Miami, FL, USA

Tel + | 56I-5|5-I544

Email exk126@med.miami.edu
Purpose: To investigate the refractive outcomes of eyes with Fuchs' endothelial corneal dystrophy (FECD) following phacoemulsification.

Methods: This is a retrospective chart review of patients with FECD who underwent phacoemulsification. Manifest refraction at the early postoperative period (1-6 weeks) and late postoperative period (3-12 months) was collected. The spherical equivalent (SE) and variance of SE from target in diopters (D) were analyzed.

Results: A total of 219 eyes from 175 FECD patients (73 FLACS, 146 conventional phacoemulsification) were included. In the early postoperative period, when comparing variance from intended target, $62 \%(n=126)$ had a SE variance of $\leq 0.5 \mathrm{D}, 22 \%(\mathrm{n}=44)$ $>0.5 \mathrm{D}$ and $\leq 1 \mathrm{D}$, and $17 \%(\mathrm{n}=34)>1$ D. In the late postoperative period, $62 \%(\mathrm{n}=85)$ had a SE variance of $\leq 0.5 \mathrm{D}, 19 \%(\mathrm{n}=26)>0.5 \mathrm{D}$ and $\leq 1 \mathrm{D}$, and $20 \%(\mathrm{n}=27)>1 \mathrm{D}$. There was no difference in the variance of SE comparing FLACS versus conventional phacoemulsification in either the early postoperative period $(\mathrm{p}=0.78)$ or the late postoperative period $(\mathrm{p}=0.29)$.

Conclusion: Patients with mild-to-moderate FECD had favorable refractive outcomes with phacoemulsification. There was no difference in refractive outcomes in eyes with FECD between the group that underwent FLACS versus the group that underwent conventional phacoemulsification.

Keywords: femtosecond laser assisted cataract surgery, Fuchs' dystrophy, Fuchs' endothelial corneal dystrophy, refractive error, refractive outcome

\section{Introduction}

One of the many challenges associated with cataract surgery in Fuchs' endothelial corneal dystrophy is predicting the refractive outcome. Factors, such as fluctuations in pre-operative data, central corneal thickness, manifest refraction, topography and tomography, as well as biometric data, serve to influence this difficulty with predictability. ${ }^{1-4}$

Femtosecond-laser assisted cataract surgery (FLACS) has been proposed to confer several advantages compared to standard phacoemulsification including shorter phacoemulsification time and less ultrasound energy usage, both of which have been shown to reduce endothelial cell loss and postoperative corneal edema in the general cataract population. ${ }^{5-11}$ In addition, it has been shown FLACS may result in a more predictable Effective Lens Position (ELP), and thereby aid in targeting the refractive outcome. ${ }^{12,13}$

As modern phacoemulsification has become more advanced, we have seen an expansion in the recommendation criteria for cataract surgery in FECD. ${ }^{14-16}$ 
Existing literature evaluating the refractive outcomes of patients with FECD after phacoemulsification - whether conventional or FLACS - is extremely sparse.

\section{Methods}

This retrospective cohort study was approved by the Institutional Review Board (IRB)/Ethics Committee at the University of Miami. The patient informed consent waiver was obtained for this retrospective study. The study was carried out with patient data confidentiality and compliance in accordance with the Declaration of Helsinki. A chart review of all patients with a prior diagnosis of FECD who underwent either conventional phacoemulsification cataract surgery or FLACS between January 1, 2014 and January 1, 2017 at Bascom Palmer Eye Institute was performed. The cases that underwent FLACS all underwent femtosecond laser capsulorrhexis formation, nucleus fragmentation, as well as corneal wound creation. All procedures were performed at the Bascom Palmer Eye Institute by the surgeons with the Comprehensive and Cornea services. Surgery was performed using either the Centurion Vision (Alcon, Irvine, CA) or Whitestar Signature (Johnson \& Johnson, New Brunswick, NJ) phacoemulsification system and any of the following femtosecond laser platforms: LenSx (Alcon, Irvine, CA), Catalys (Johnson \& Johnson, New Brunswick, NJ), or Victus (Bausch \& Lomb Surgical, Rancho Cucamonga, CA).

\section{Inclusion and Exclusion Criteria}

A search for charts within the electronic medical record system with concurrent CPT procedural codes for cataract surgery $(66,982$ and 66,984$)$ and ICD-10 (H18.5) or ICD-9 (371.57) diagnostic codes for FECD yielded a total of 753 cases. Cases with prior keratoplasty or glaucoma surgery, concurrent cataract extraction with keratoplasty, complications related to cataract surgery or laser application, incomplete records, and follow-up time less than 3 months were excluded. Eyes that required keratoplasty in the 12-month period following cataract surgery as a result of corneal decompensation were also excluded. A total of 219 eyes (73 FLACS and 146 conventional phacoemulsification) from 175 patients were evaluated in this study.

\section{Chart Review and Data Collection}

The charts were evaluated for demographic and clinical variables including age, gender, date, type of cataract surgery (conventional vs FLACS), preoperative best- corrected visual acuity (BCVA), and central corneal thickness (CCT) by ultrasound pachymetry. Nuclear sclerosis was assessed by slit-lamp examination and graded based on the Wisconsin Cataract Grading System. ${ }^{17}$ The clinical grade for FECD was assigned according to the degree of corneal guttae and edema documented upon slit-lamp exam as previously described. ${ }^{18}$ All cases of FECD were categorized as mild (grades 1-2) or moderate (grades 2.54). Advanced cases of FECD (grades 5-6) were excluded as they underwent concurrent endothelial keratoplasty. The BCVA, CCT (when available), and corneal edema findings documented at each postoperative visit were analyzed. The spherical equivalence (SE) and variance of SE from target refraction in diopters (D) were analyzed.

\section{Follow-Up Periods}

Due to the retrospective nature of the study, postoperative visits were not available to all patients at consistent follow-up times. Therefore, we divided the follow-up into broad windows: the early postoperative period (including visits from 1 to 6 weeks following surgery) and the late postoperative period (including visits from 3 to 12 months following surgery). If a patient had more than one visit per period, the visit closest to the center of the window was selected for analysis.

\section{Statistical Analyses}

Categorical and ordinal variables were summarized with counts and percentages, while continuous variables were summarized with means and standard deviations (SD). Due to the inclusion of both eyes of some patients, statistical analyses comparing the femtosecond group to the conventional treatment group, as well as assessing the influence of risk factors, were conducted using Generalized estimating equation (GEE) models (IBM SPSS Statistics version 22, Armonk NY) employing exchangeable correlation structure and interval, binomial, or multinomial links as appropriate.

\section{Results}

\section{Baseline Patient Characteristics}

A total of 175 patients were identified. Out of the 175 patients, 52 patients had undergone conventional phacoemulsification, and 123 had undergone FLACS. Two eyes were included from a single patient as long as the study eye met the Inclusion and Exclusion criteria. A total of 219 eyes were included in the study, with 73 eyes in the 
Table I Baseline Characteristics in Risk Factor Analysis ${ }^{€}$ for Fuchs Endothelial Corneal Dystrophy Patients

\begin{tabular}{|c|c|c|c|}
\hline Laser Treatment & Femtosecond Laser & Conventional & $\begin{array}{l}\text { Generalized Estimating } \\
\text { Equation (GEE) Model P- value }\end{array}$ \\
\hline Number of Patients & 52 & 123 & \\
\hline Number of Eyes for Analyses & 73 & 146 & \\
\hline Age $(y)$, mean age $\pm S D$ & $74.1 \pm 7.5$ & $75.2 \pm 8.5$ & 0.58 \\
\hline $\begin{array}{l}\text { Best-corrected visual acuity, Mean } \\
\text { logMAR (BCVA) } \pm S D \text { [Range] }\end{array}$ & $0.231 \pm 0.163$ & $0.331 \pm 0.264$ & 0.001 \\
\hline $\begin{array}{l}\text { Visual Acuity Group, N (\%) } \\
\begin{array}{l}\geq 20 / 30 \\
20 / 30-60 \\
20 / 70-5 / 200\end{array}\end{array}$ & $\begin{array}{l}40(56) \\
30(42) \\
2(3)\end{array}$ & $\begin{array}{l}60(4 I) \\
62(43) \\
24(16)\end{array}$ & 0.024 \\
\hline $\begin{array}{l}\text { Central corneal thickness }(\mu \mathrm{m})^{\Phi,} \text { mean } \\
\pm \text { SD [Range] } \\
\text { Not collected } \mathrm{N},(\%) \\
\text { Collected } \mathrm{N},(\%)\end{array}$ & $\begin{array}{l}576 \pm 39[496,623] \\
55(75) \\
18(25)\end{array}$ & $\begin{array}{l}574 \pm 39[496,648] \\
83(57) \\
63(43)\end{array}$ & $\begin{array}{l}0.81 \\
0.038\end{array}$ \\
\hline $\begin{array}{l}\text { Gender N, (\%) } \\
\text { Male } \\
\text { Female }\end{array}$ & $\begin{array}{l}21(29) \\
52(7 I)\end{array}$ & $\begin{array}{l}48(33) \\
98(67)\end{array}$ & 0.83 \\
\hline $\begin{array}{l}\text { Corneal guttata grade } \mathrm{N},(\%) \\
\quad 0.5-1.0 \\
1.5-2.0 \\
2.5-3.0 \\
3.5-4.0\end{array}$ & $\begin{array}{l}16(24) \\
24(36) \\
22(33) \\
5(8)\end{array}$ & $\begin{array}{l}42(33) \\
38(30) \\
35(28) \\
12(9)\end{array}$ & 0.67 \\
\hline $\begin{array}{l}\text { Cataract grade } \mathrm{N},(\%) \\
0.5-1.0 \\
1.5-2.0 \\
2.5-3.0 \\
3.5-4.0\end{array}$ & $\begin{array}{l}7(10) \\
34(49) \\
29(4 I) \\
0\end{array}$ & $\begin{array}{l}5(4) \\
84(58) \\
52(36) \\
3(2)\end{array}$ & 0.16 \\
\hline $\begin{array}{l}\text { Target refractions } \\
\text { Mean (SD) } \\
\text { [Range] }\end{array}$ & $\begin{array}{l}-0.3(0.3) \\
{[-2,0]}\end{array}$ & $\begin{array}{l}-0.1(0.1) \\
{[-3,0]}\end{array}$ & 0.005 \\
\hline
\end{tabular}

Notes: ${ }^{\Phi}$ Preoperative central corneal thickness was not available for every patient; values were calculated from $n=18$ (femtosecond laser) and $n=63$ (conventional);

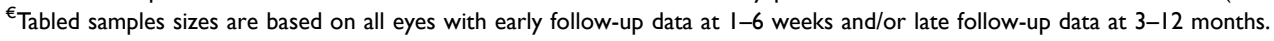

conventional phacoemulsification group, and 146 eyes in the FLACS group. Demographics were similar between treatment groups (Table 1). Eyes with pre-operative CCT measurement were more common in the conventional group $(43 \%, \mathrm{n}=63)$ than in the FLACS group $(25 \%$, $\mathrm{n}=18, \mathrm{p}=0.038)$. However, there was no significant difference between the mean thickness values $(p=0.81)$. Conventionally treated eyes also had visual acuity of $0.1 \log$ MAR (approximately one Snellen line on average) worse than the FLACS eyes $(p=0.001)$. Notably, there was no statistically significant difference in cataract grade $(\mathrm{p}=0.16)$ and corneal guttata grade $(\mathrm{p}=0.67)$.

\section{Spherical Equivalent Outcomes}

Early and late follow-up period Spherical Equivalent (SE) outcomes for both the FLACS and conventional groups were investigated and compared (Tables 2 and 3, Figure 1). The mean target SE correction for eyes in the FLACS group was -0.3 diopter (D) (range of $-2 \mathrm{D}$ to plano). The mean target SE correction for eyes in the conventional group was -0.1 diopter (D) (range of $-3 \mathrm{D}$ to plano). The mean deviation from the target SE correction was $-0.10 \mathrm{D} \pm 0.83$ in the early postoperative period for all eyes. The mean deviation from target SE correction was $-0.14 \mathrm{D} \pm 0.85$ in the late follow-up group for all 
Table 2 Eyes with Early (I-6 Weeks) Postoperative Follow-Up

\begin{tabular}{|c|c|c|c|c|}
\hline \multicolumn{5}{|c|}{ Eyes with Early (I-6 Week) Postoperative Follow-Up } \\
\hline & Femtosecond & Conventional & Total & $\begin{array}{c}\text { GEE } \\
\text { p-value }\end{array}$ \\
\hline $\mathrm{N}$ Eyes & 70 & 134 & 204 & \\
\hline $\begin{array}{l}\text { Preoperative Spherical Equivalent, } \\
\text { Mean } \pm \text { SD [range] }\end{array}$ & $\mathrm{N} / \mathrm{A}$ & $\mathrm{N} / \mathrm{A}$ & N/A & $\mathrm{N} / \mathrm{A}$ \\
\hline $\begin{array}{l}\text { Preoperative logMAR BCVA } \\
\text { Mean } \pm \text { SD [range] }\end{array}$ & $0.23 \pm 0.17[0,1.0]$ & $0.32 \pm 0.26[-0.1,1.6]$ & $0.29 \pm 0.24[-0.1,1.6]$ & 0.003 \\
\hline $\begin{array}{l}\text { Preoperative Acuity Group, N (\%) } \\
\geq 20 / 30 \\
60 \\
20 / 70-5 / 200\end{array}$ & $\begin{array}{c}38(55 \%) \\
29(42 \%) \\
2(3 \%)\end{array}$ & $\begin{array}{l}57(43 \%) \\
56(42 \%) \\
21(16 \%)\end{array}$ & $\begin{array}{l}95(47 \%) \\
85(42 \%) \\
23(11 \%)\end{array}$ & 0.042 \\
\hline \multicolumn{5}{|c|}{ Early Postoperative Spherical Equivalent, target corrected $\left(\mathbf{S E}_{\mathrm{TC}}\right)$} \\
\hline $\mathrm{SE}_{\mathrm{TC}}$, Mean $\pm \mathrm{SD}$ [range] & $-0.07 \pm 0.89[-2.00,2.75]$ & $-0.11 \pm 0.80[-2.63,3.25]$ & $-0.10 \pm 0.83[-2.63,3.25]$ & 0.78 \\
\hline $\begin{array}{l}\text { Absolute value } \mathrm{SE}_{\mathrm{TC}} \text {, Mean } \pm \mathrm{SD} \\
\text { [range] }\end{array}$ & $0.66 \pm 0.60[0,2.75]$ & $0.56 \pm 0.58[0,3.25]$ & $0.60 \pm 0.59[0,3.25]$ & 0.25 \\
\hline $\begin{array}{l}\text { Outcome classification by deviation } \\
\text { from target refraction, } \mathrm{N}(\%) \\
\text { Good }(\leq 0.5 \mathrm{D}) \\
\text { Fair }(>0.5 \text { to } \leq \mathrm{ID}) \\
\text { Poor }(>\mathrm{ID})\end{array}$ & $\begin{array}{l}39(56 \%) \\
19(27 \%) \\
12(17 \%)\end{array}$ & $\begin{array}{l}87(65 \%) \\
25(19 \%) \\
22(16 \%)\end{array}$ & $\begin{array}{c}126(62 \%) \\
44(22 \%) \\
34(17 \%)\end{array}$ & 0.24 \\
\hline \multicolumn{5}{|c|}{ Early Postoperative Visual acuity } \\
\hline logMAR BCVA Mean \pm SD [range] & $0.14 \pm 0.14[0,0.7]$ & $0.17 \pm 0.25[-0.1,2.0]$ & $0.16 \pm 0.22[-0.1,2.0]$ & 0.18 \\
\hline $\begin{array}{l}\text { Visual Acuity Group } \\
\begin{array}{l}\geq 20 / 30 \\
20 / 30-60 \\
20 / 70-5 / 200\end{array}\end{array}$ & $\begin{array}{c}57(81 \%) \\
12(17 \%) \\
I(1 \%)\end{array}$ & $\begin{array}{c}97(73 \%) \\
28(21 \%) \\
8(6 \%)\end{array}$ & $\begin{array}{c}\text { I54 (76\%) } \\
40(20 \%) \\
9(4 \%)\end{array}$ & 0.29 \\
\hline
\end{tabular}

eyes. In the group that underwent FLACS, the mean deviation from target SE correction was $-0.07 \mathrm{D} \pm 0.89$ in the early postoperative period and $-0.10 \mathrm{D} \pm 0.68$ in the late postoperative period. In the conventional group, the mean deviation from target $\mathrm{SE}$ correction was $-0.11 \mathrm{D} \pm$ 0.80 in the early postoperative period and $-0.15 \mathrm{D} \pm 0.94$ in the late postoperative period. In both the early postoperative period and the late postoperative period, there was no statistical difference $(p>0.005)$ when comparing the mean deviation from target SE between FLACS and conventional groups $(p=0.78$ and 0.47 , respectively for the two follow-up periods). For the early period, the corresponding 95\% CI for the regression coefficient 0.039 (representing the difference between the mean deviation from target SE in the FLACS group and the mean deviation from target $\mathrm{SE}$ in the conventional group) was -0.23 ,
0.31. For the later period, the corresponding 95\% CI for the regression coefficient 0.12 (representing the difference between the mean deviation from target SE in the FLACS group and the mean deviation from target $\mathrm{SE}$ in the conventional group) was $-0.21,0.45$. There was no difference between the groups with respect to the absolute value of the target corrected SE (Tables 2 and 3).

The refractive outcomes of groups in both the early and late postoperative periods were further divided into Good (defined as having a mean deviation of $\leq 0.5 \mathrm{D}$ from target $\mathrm{SE}$ ), Fair (defined as having a mean deviation of $>0.5$ $\mathrm{D}$ and $\leq 1.0 \mathrm{D}$ from target SE) and Poor (defined as having a mean deviation of $>1.0 \mathrm{D}$ from target SE). In the FLACS group, the percentages to achieve a SE that was within $\pm 0.5 \mathrm{D}$ from the intended target (Good refractive outcome) for the early and late postoperative periods were $56 \%$ 
Table 3 Eyes with Late Postoperative Follow-Up (3-12 Months)

\begin{tabular}{|c|c|c|c|c|}
\hline & Femtosecond & Conventional & Total & $\begin{array}{c}\text { GEE } \\
\text { p-value }\end{array}$ \\
\hline N Eyes & 50 & 88 & 138 & \\
\hline $\begin{array}{l}\text { Preoperative Spherical Equivalent, } \\
\text { Mean } \pm \text { SD [range] }\end{array}$ & N/A & $\mathrm{N} / \mathrm{A}$ & N/A & N/A \\
\hline $\begin{array}{l}\text { Preoperative logMAR BCVA Mean } \\
\pm \text { SD [range] }\end{array}$ & $0.21 \pm 0.16[0,1.0]$ & $0.40 \pm 0.29[0,1.6]$ & $0.33 \pm 0.27[0,1.6]$ & $\mathrm{P}<0.00 \mathrm{I}$ \\
\hline $\begin{array}{l}\text { Preoperative Acuity Group, N (\%) } \\
\begin{array}{l}\geq 20 / 30 \\
20 / 30-60 \\
20 / 70-5 / 200\end{array}\end{array}$ & $\begin{array}{c}31 \text { (63\%) } \\
\text { I7 (35\%) } \\
\text { I (2\%) }\end{array}$ & $\begin{array}{l}24(27 \%) \\
44(50 \%) \\
20(23 \%)\end{array}$ & $\begin{array}{l}55(40 \%) \\
61(45 \%) \\
21(15 \%)\end{array}$ & 0.001 \\
\hline \multicolumn{5}{|c|}{ Postoperative Spherical Equivalent, target corrected $\left(\mathrm{SE}_{\mathrm{TC}}\right)$} \\
\hline $\mathrm{SE}_{\mathrm{TC}}$, Mean $\pm \mathrm{SD}$ [range] & $-0.10 \pm 0.68[-2.00,2.25]$ & $-0.15 \pm 0.94[-2.13,2.75]$ & $-0.14 \pm 0.85[-2.13,2.75]$ & 0.47 \\
\hline $\begin{array}{l}\text { Absolute value } \mathrm{SE}_{\mathrm{TC}} \text {, Mean } \pm \mathrm{SD} \\
\text { [range] }\end{array}$ & $0.51 \pm 0.46[0.2 .25]$ & $0.70 \pm 0.64[0,2.75]$ & $0.63 \pm 0.59[0,2.75]$ & 0.29 \\
\hline $\begin{array}{l}\text { Outcome classification by deviation } \\
\text { from target refraction, } \mathrm{N}(\%) \\
\text { Good }(\leq 0.5 \mathrm{D}) \\
\text { Fair }(>0.5 \text { to } \leq \text { ID) } \\
\text { Poor }(>I D)\end{array}$ & $\begin{array}{c}34(68 \%) \\
\text { II (22\%) } \\
5(10 \%)\end{array}$ & $\begin{array}{l}51(58 \%) \\
15(17 \%) \\
22(25 \%)\end{array}$ & $\begin{array}{l}85(62 \%) \\
26(19 \%) \\
27(20 \%)\end{array}$ & 0.11 \\
\hline
\end{tabular}

$(\mathrm{n}=39)$ and $68 \%(\mathrm{n}=34)$, respectively (Tables 2 and 3$)$. In the conventional group, the percentages to achieve a $\mathrm{SE}$ that was within $\pm 0.5 \mathrm{D}$ from the intended target (Good refractive outcome) for the early and late postoperative periods were $65 \%(\mathrm{n}=87)$ and $58 \%(\mathrm{n}=51)$, respectively (Tables 2 and 3). There was no statistical significance in the mean deviation from target SE between the two groups in either the early postoperative period $(\mathrm{p}=0.78)$ or the late postoperative period $(\mathrm{p}=0.29)$. For all FECD eyes, in the early postoperative period, $62 \%(n=126)$ of eyes were found to be in the Good category, 22\% $(n=44)$ in the Fair category, and $17 \% \quad(n=34)$ in Poor category (Table 2). In the late postoperative period, $62 \%(\mathrm{n}=85)$ of eyes were found to be in the Good category, $19 \%$ $(n=26)$ in the Fair category, and $20 \%(n=27)$ in the Poor category (Table 3 ).

There were no statistically significant differences in outcome classifications (Tables 2 and 3) between the FLACS and conventional groups at either early followup $(\mathrm{p}=0.24)$ or late follow-up $(\mathrm{p}=0.11)$. Of note, at late follow-up $15 \%$ more (total $n=22$ ) conventionally treated eyes were found to have poor outcomes than FLACS treated eyes.

\section{Drift in Spherical Equivalent Refraction from Early-to-Late Postoperative Period}

Comparison of outcome classifications within the two treatment groups reveals some shift in outcomes between early and late postoperative periods (Tables 2 and 3). However, these rates cannot be directly compared because the two follow-up periods included different subsets of eyes. Therefore, we examined the drift in SE from early-to-late period in the 47 FLACS and 76 conventionally treated eyes who contributed data for both follow-up periods. Figure 2 presents SE drift from early-to-late follow-up by treatment group. There was no statistically significant difference between the groups in drift categories ( $\mathrm{p}=0.45$, multinomial GEE); however, of note, $10(13 \%)$ of eyes receiving conventional treatment experienced a change in SE of 2 or more diopters from early to late follow-up compared to none of the FLACS treated eyes. These large drifts did not always result in a worse outcome. Of these 10 eyes, 5 of 7 with a Poor early outcome achieved a Fair or Good outcome at late follow-up; nevertheless, 3 eyes with Good early follow-up outcome had Poor late follow-up outcomes. 

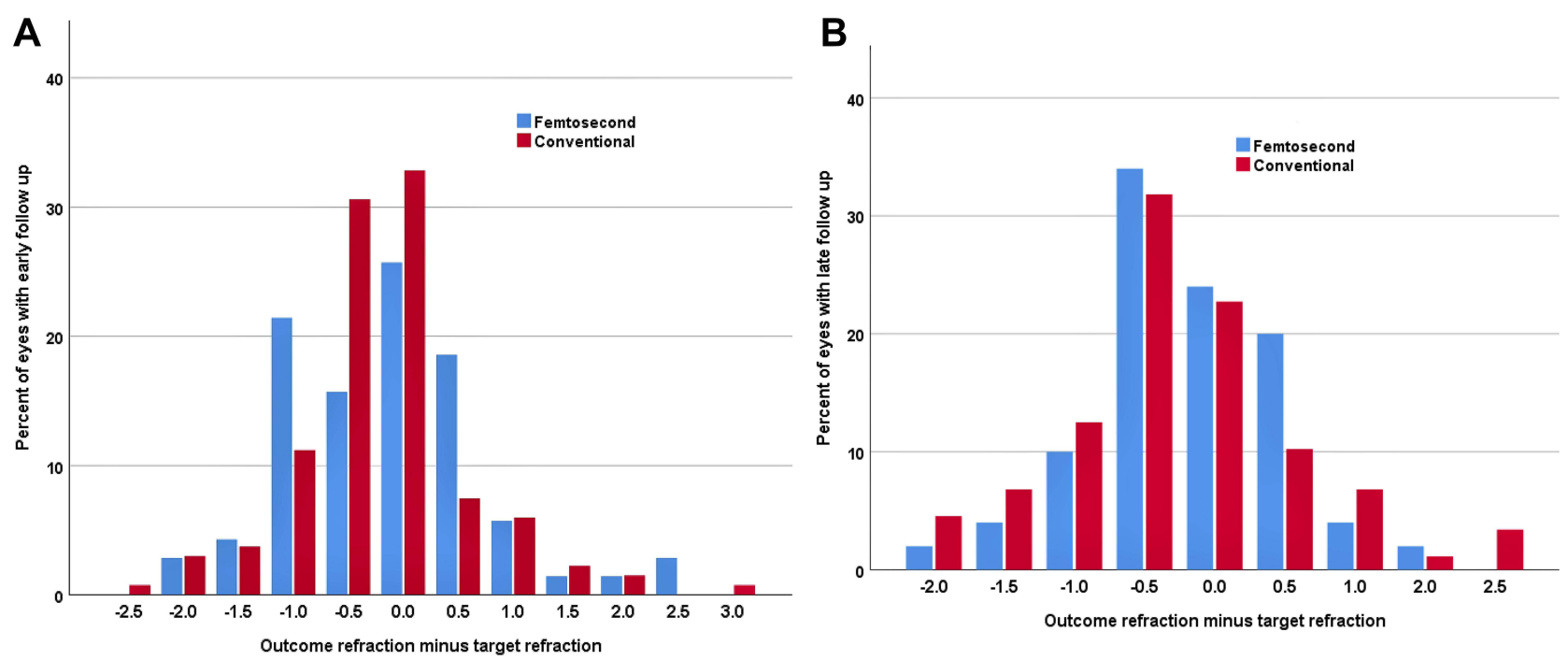

Figure I Spherical equivalent outcome by type of cataract surgery for early follow period (A) and late follow-up period 9 (B).

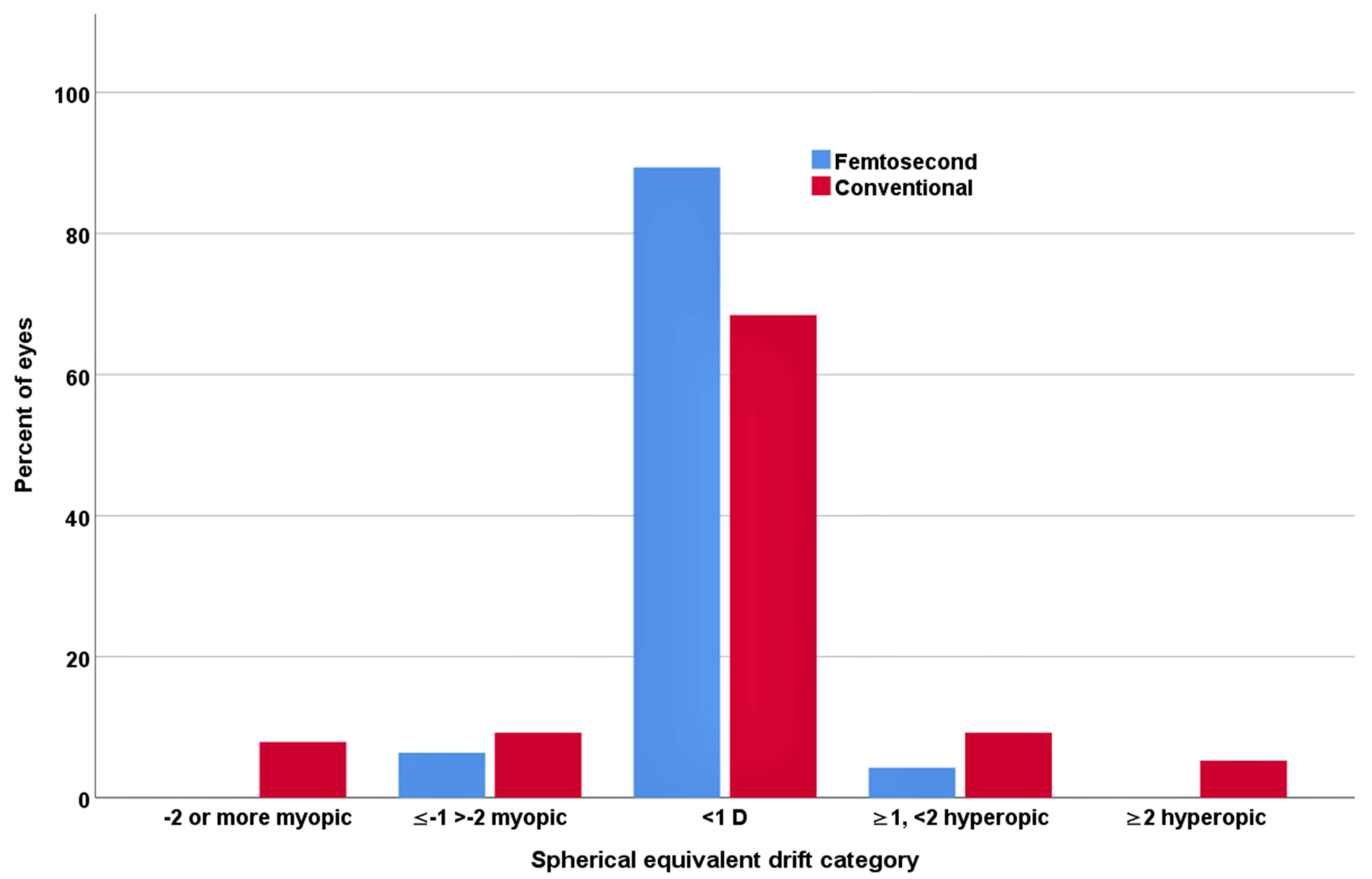

Figure 2 Spherical Equivalent drift from early-to-late follow-up period by cataract surgery type.

\section{Risk Factors for Poor Refractive Outcome} The study population was quite heterogeneous with respect to preoperative ocular characteristics, some of which differed between the FLACS and conventional groups (Table 1). Therefore, we assessed the influence of these characteristics on Poor early and late spherical equivalent outcomes (Table 4). With the exception of preoperative cataract status, none of the putative risk factors was statistically significantly related to Poor outcome at either early or late follow up. The influence of cataract was 
Table 4 Preoperative Risk Factors for Poor Outcome (>ID from Target Refraction)

\begin{tabular}{|c|c|c|}
\hline & \multicolumn{2}{|c|}{ Follow Up Period } \\
\hline & Early & Late \\
\hline Number of Eyes & 204 & 138 \\
\hline$N(\%)$ of eyes with poor outcome & $34(17 \%)$ & $27(20 \%)$ \\
\hline Risk factor & \multicolumn{2}{|c|}{ Odds ratio $(95 \% \mathrm{Cl}) * \dagger$} \\
\hline Age ( 10 years older age) & $0.97(0.62, I .5 \mathrm{I}) \mathrm{P}=0.88$ & $0.75(0.46,1.22) \mathrm{P}=0.24$ \\
\hline Best-corrected visual acuity ( 0.3 worse logMAR acuity & $1.17(0.74,1.85) \mathrm{P}=0.50$ & $\mathrm{I} .46(0.92,2.3 \mathrm{I}) \mathrm{P}=0.1 \mathrm{I}$ \\
\hline CCT (if measured, 50um thicker) & $1.09(0.46,2.59) \mathrm{P}=0.84$ & $0.84(0.32,2.18) \mathrm{P}=0.84$ \\
\hline Gender & $P=0.52$ & $\mathrm{P}=0.89$ \\
\hline Male & $0.76(0.33,1.76)$ & $0.94(0.38,2.34)$ \\
\hline Female & Reference & Reference \\
\hline Visual Acuity Group, N (\%) & $\mathrm{P}=0.98$ & $P=0.13$ \\
\hline$\geq 20 / 30$ & Reference & Reference \\
\hline $20 / 30-60$ & $0.94(0.44,2.01)$ & $1.23(0.43,3.52)$ \\
\hline $20 / 70-5 / 200$ & $1.02(0.31,3.33)$ & $3.32(0.87,1 \mathrm{I} .3)$ \\
\hline Central corneal measured & $P=0.66$ & $\mathrm{P}=0.86$ \\
\hline Yes & $1.19(0.55,2.57)$ & $1.08(0.46,2.56)$ \\
\hline No & Reference & Reference \\
\hline Corneal guttata grade N, (\%) & $P=0.97$ & $P=0.84$ \\
\hline $0.5-1.0$ & Reference & Reference \\
\hline $1.5-2.0$ & $1.16(0.43,3.15)$ & $1.96(0.44,8.69)$ \\
\hline $2.5-3.0$ & $0.95(0.34,2.61)$ & $1.25(0.32,4.88)$ \\
\hline $3.5-4.0$ & $0.92(0.18,4.78)$ & $\mathrm{I} .40(0.44,4.46)$ \\
\hline Cataract grade N, (\%) & $\mathrm{P}<0.00 \mathrm{I}$ & 0.90 \\
\hline $0.5-1.0$ & Reference & Reference \\
\hline $1.5-2.0$ & $1.32(0.29,6.05)$ & I.2I $(0.25,5.95)$ \\
\hline $2.5-3.0$ & $0.89(0.17,4.69)$ & $1.44(0.26,8.17)$ \\
\hline $3.5-4.0$ & $5.73(1.32,24.9)$ & None present \\
\hline Target refraction (D) & $\mathrm{P}=0.75$ & $\mathrm{P}=0.47$ \\
\hline$>-0.5$ & Reference & Reference \\
\hline$-0.75,-0.5$ & $0.94(0.34,2.60)$ & $0.45(0.13,1.60)$ \\
\hline$\leq-1.0$ & $1.58(0.46,5.38)$ & $(0.87(0.17,4.40)$ \\
\hline
\end{tabular}

Notes: *Univariate GEE, not adjusted for type of laser treatment; ${ }^{\dagger}$ Reference $=$ Odds ratio reference category.

limited to grades $>3$ (3 eyes) which had odds of Poor refractive outcome 5.7 times greater than those of eyes with less severe cataract. None of these patients returned for examination in the later follow-up period.

The presence of postoperative corneal edema was examined in relation to the refractive outcome categorization. There was no statistical significance in the refractive outcome distribution when comparing absence versus presence of corneal edema in both the early (Table 5, $\mathrm{p}=0.15$ ) and late postoperative periods (Table $6, \mathrm{p}=0.27$ ).

The fluctuation in SE from early to late period was found to be $0.02 \pm 0.59$ in the FLACS group versus $-0.12 \pm 1.20$ in the conventional group. There was no statistical difference between the two groups $(\mathrm{P}=0.3)$. However, a wider range was observed in the conventional group $[-3.50 \mathrm{D}$ to $+3.25 \mathrm{D}]$ compared to the 
Table 5 Refractive Outcomes and Postoperative Edema, Early Postoperative Period

\begin{tabular}{|l|l|l|}
\hline $\begin{array}{l}\text { Refractive } \\
\text { Outcome }\end{array}$ & $\begin{array}{l}\text { Absence of } \\
\text { Postoperative } \\
\text { Edema }\end{array}$ & $\begin{array}{l}\text { Presence of } \\
\text { Postoperative Edema }\end{array}$ \\
\hline $\begin{array}{l}\text { Good } \\
\text { Fair }\end{array}$ & $61(66 \%)$ & $23(51 \%)$ \\
Poor & $14(15 \%)$ & $10(22 \%)$ \\
$18(19 \%)$ & $127 \%)$ \\
\hline
\end{tabular}

Table 6 Refractive Outcomes and Postoperative Edema, Late Postoperative Period

\begin{tabular}{|c|c|c|}
\hline $\begin{array}{l}\text { Refractive } \\
\text { Outcome }\end{array}$ & $\begin{array}{l}\text { Absence of } \\
\text { Postoperative } \\
\text { Edema }\end{array}$ & $\begin{array}{l}\text { Presence of } \\
\text { Postoperative Edema }\end{array}$ \\
\hline Good & 72 (63\%) & 12 (52\%) \\
\hline Fair & $20(17 \%)$ & $4(17 \%)$ \\
\hline Poor & $23(20 \%)$ & 7 (30\%) \\
\hline
\end{tabular}

FLACS group $[-1.25 \mathrm{D}$ to $+1.75 \mathrm{D}]$ (Table 7). The regression coefficient was found to be 0.18 with a hyperopic increase in FLACS at the late time-point.

\section{Discussion}

Fuchs' Endothelial Corneal Dystrophy (FECD) is a disease known to adversely affect the outcome of phacoemulsification surgery due to its direct risks of subsequent corneal decompensation, and authors have previously described strategic approaches to cataract surgery in this patient population. ${ }^{14-16,19}$ As modern phacoemulsification has become more advanced, studies have demonstrated that phacoemulsification can be safely done in FECD. ${ }^{14-16}$

Refractive outcomes of FECD patients undergoing phacoemulsification remain sparsely documented, however. Fritz et al have shown via Scheimpflug image studies that the curvature of the cornea affects the refractive outcome in their study, due to the oblate posterior profile of FECD corneas. $^{3}$ Others have proposed that in FECD corneas, the presence of stromal edema affects the refractive state. ${ }^{20,21}$

In the past few decades, there have been advancements in phacoemulsification equipment and in surgical technique, and improved accuracy of biometric measurements and of intraocular lens (IOL) power formulas. ${ }^{22,23}$ Patient expectations have also risen with cataract surgery, and thus the demand for a desirable refractive outcome makes up a large part of patient expectations. ${ }^{23-25}$

\section{Femtosecond Laser Cataract Surgery}

FLACS is one of the newest technological advancements in modern-day phacoemulsification surgery. The clinical advantages of FLACS over conventional phacoemulsification are continually being investigated and debated, although for many parameters, the technique seems to yield similar refractive and safety outcomes relative to conventional phacoemulsification. ${ }^{6,26-29}$ In studies comparing refractive outcomes, FLACS was shown to offer a more favorable outcome; this has been attributed to intraocular lens stability, and more predictable effective lens position (ELP) and capsulorrhexis size. ${ }^{30,31}$

The study of FLACS outcomes in FECD patients has garnered increasing attention in the last few years, as this group of patients are particularly vulnerable to corneal decompensation with cataract surgery. ${ }^{14}$ Previous studies show mixed results in terms of clinically significant advantage in FECD when comparing rates of corneal edema and rates of corneal decompensation. ${ }^{32-35}$

\section{FECD Cornea and Refractive Challenges}

In FECD patients undergoing cataract surgery, there is the additional challenge of predicting the refractive outcome in these eyes. In particular, a hyperopic trend has been described, and this is thought to be due to the posterior corneal curvature changes from edema, ${ }^{3,20}$ as well as the large change in refractive index at the anterior corneal surface. $^{36}$

As cataract surgery has evolved, so have patient expectations. Most patients desire a reasonably low residual

Table 7 Spherical Equivalence Change from Early to Late Period

\begin{tabular}{|c|c|c|c|c|}
\hline & Femtosecond & Conventional & Total & $\begin{array}{l}\text { GEE } \\
\text { P-value }\end{array}$ \\
\hline $\mathrm{N}$ & 47 & 76 & 123 & \\
\hline $\begin{array}{l}\text { SE change from early to late Mean } \\
\pm \text { SD [range] }\end{array}$ & $0.02 \pm 0.59[-1.25,1.75]$ & $-0.12 \pm 1.20[-3.50,3.25]$ & $-0.06 \pm 1.01[-3.50,3.25]$ & 0.30 \\
\hline
\end{tabular}


refractive error after cataract surgery. Based on the severity of the Fuchs' Dystrophy, an appropriate refractive target is determined by the surgeon; in particular, with more severe disease, mild residual myopia is targeted with the expectation that the patient may eventually undergo endothelial keratoplasty with an anticipated hyperopic shift. ${ }^{34,37,38}$

When comparing the fluctuation of SE from the early to late period, there was no statistical difference between the two groups $(\mathrm{P}=0.3)$. Interestingly, a wider range was observed in the conventional group $[-3.50 \mathrm{D}$ to $+3.25 \mathrm{D}]$ compared to the FLACS group $[-1.25 \mathrm{D}$ to $+1.75 \mathrm{D}]$. The wide fluctuation range from the early to late period in both groups is noteworthy - this may be clinically relevant to the surgeon during the early postoperative period when addressing a patient who is anxious or unhappy about the refractive results of cataract surgery. Our study suggests that it may be prudent to wait longer in order to assess the true refractive results in the FECD patient.

\section{Limitations}

The retrospective nature of this investigation means there is inherent bias. In addition, the procedures were performed by different surgeons with varying phacoemulsification techniques. There was also variability amongst femtosecond laser platforms and phacoemulsification systems. In addition, the CCT was not consistently recorded for every eye. While the Spherical Equivalent was our main refractive outcome measure, we did not include astigmatism or astigmatism-correcting treatments because the disease progression of FECD is known to create posterior corneal changes and induced astigmatism. ${ }^{39}$ In addition, the retrospective nature of the study would mean that there would be variances in the surgeons' individual clinical practice preferences for astigmatism correction. Furthermore, in-depth tomographic study of posterior corneal changes as well as astigmatism in these eyes was not possible as tomographic imaging was not consistently performed. The limitation of examining the presence or absence of corneal edema was that we relied on the clinician's subjective documentation in the charts. Another limitation was the lack of IOL formula documentation by the surgeons. However, these are factors common to clinical retrospective studies like ours. A controlled prospective study would be warranted to further study these areas.

\section{Summary}

In this study, we sought to investigate the overall refractive outcomes in this population. Despite the afore-mentioned challenges presented by the FECD corneas, patients with mild-to-moderate FECD could still expect favorable refractive outcomes (the patients with severe classification were omitted per our exclusion criteria as these eyes either underwent concurrent keratoplasty or experienced corneal decompensation). We did not find statistically significant differences in outcome classifications (Tables 2 and 3) between the FLACS and conventional groups at either early follow-up $(p=0.24)$ or late follow-up $(p=0.11)$. We did not find a statistical significance when looking at the absence or presence of postoperative corneal edema and the effects on refractive outcomes.

\section{Disclosure}

The study was funded in part by the NIH Core Center Grant P30EY014801. Submitted work was presented at the American Academy of Ophthalmology, October 2018, Chicago, Illinois. Dr Patrice Persad reports grants from the National Institutes of Health - National Eye Institute, grants from Research to Prevent Blindness, during the conduct of the study. Professor Kendall Donaldson reports consulting from Alcon, Johnson and Johnson, Allergan, Avellino, Omeros, Novartis, Kala Pharmaceuticals, Science Based Health, Carl Zeiss Meditec, and Lumenis, outside the submitted work. The authors report no other conflicts of interest in this work.

\section{References}

1. Sun SY, Wacker K, Baratz KH, Patel SV. Determining subclinical edema in fuchs endothelial corneal dystrophy: revised classification using Scheimpflug tomography for preoperative assessment. Ophthalmology. 2019;126(2):195-204. doi:10.1016/j. ophtha.2018.07.005

2. Falkenberg B, Kutschan A, Wiegand W. [Analysis of optical parameters after cataract surgery and implantation of foldable lens]. Ophthalmologe. 2005;102(6):587-591. doi:10.1007/s00347-0041135-9. [Portugese]

3. Fritz M, Grewing V, Böhringer D, et al. Avoiding hyperopic surprises after descemet membrane endothelial keratoplasty in Fuchs dystrophy eyes by assessing corneal shape. Am J Ophthalmol. 2019;197:1-6.

4. Gupta R, Kinderyte R, Jacobs DS, Jurkunas UV. Elimination of anterior corneal steepening with descemet membrane endothelial keratoplasty in a patient with Fuchs dystrophy and keratoconus: implications for IOL calculation. Cornea. 2017;36(10):1260-1262. doi:10.1097/ ICO.0000000000001309

5. Takács AI, Kovacs I, Mihaltz K, Filkorn T, Knorz MC, Nagy ZZ. Central corneal volume and endothelial cell count following femtosecond laser-assisted refractive cataract surgery compared to conventional phacoemulsification. J Refract Surg. 2012;28(6):387-391. doi:10.3928/1081597X-20120508-02

6. Popovic M, Campos-Moller X, Schlenker MB, Ahmed II. Efficacy and safety of femtosecond laser-assisted cataract surgery compared with manual cataract surgery: a meta-analysis of 14567 eyes. Ophthalmology. 2016;123(10):2113-2126. 
7. Nagy ZZ, McAlinden C. Femtosecond laser cataract surgery. Eye Vis (Lond). 2015;2(1):11. doi:10.1186/s40662-015-0021-7

8. Abell RG, Darian-Smith E, Kan JB, Allen PL, Ewe SY, Vote BJ. Femtosecond laser-assisted cataract surgery versus standard phacoemulsification cataract surgery: outcomes and safety in more than 4000 cases at a single center. J Cataract Refract Surg. 2015;41 (1):47-52. doi:10.1016/j.jcrs.2014.06.025

9. Abell RG, Kerr NM, Vote BJ. Toward zero effective phacoemulsification time using femtosecond laser pretreatment. Ophthalmology. 2013;120(5):942-948. doi:10.1016/j.ophtha.2012.11.045

10. Abell RG, Kerr NM, Howie AR, Mustaffa Kamal MA, Allen PL, Vote BJ. Effect of femtosecond laser-assisted cataract surgery on the corneal endothelium. J Cataract Refract Surg. 2014;40 (11):1777-1783. doi:10.1016/j.jcrs.2014.05.031

11. Conrad-Hengerer I, Al Juburi M, Schultz T, Hengerer FH, Dick HB. Corneal endothelial cell loss and corneal thickness in conventional compared with femtosecond laser-assisted cataract surgery: three-month follow-up. $J$ Cataract Refract Surg. 2013;39 (9):1307-1313. doi:10.1016/j.jcrs.2013.05.033

12. Packer M, Teuma EV, Glasser A, Bott S. Defining the ideal femtosecond laser capsulotomy. Br J Ophthalmol. 2015;99(8):1137-1142. doi:10.1136/bjophthalmol-2014-306065

13. Hatch KM, Talamo JH. Laser-assisted cataract surgery: benefits and barriers. Curr Opin Ophthalmol. 2014;25(1):54-61. doi:10.1097/ ICU.0000000000000013

14. Seitzman GD. Cataract surgery in Fuchs' dystrophy. Curr Opin Ophthalmol. 2005;16(4):241-245.

15. Seitzman GD, Gottsch JD, Stark WJ. Cataract surgery in patients with Fuchs' corneal dystrophy: expanding recommendations for cataract surgery without simultaneous keratoplasty. Ophthalmology. 2005;112(3):441-446. doi:10.1016/j.ophtha.2004.10.044

16. Eghrari AO, Daoud YJ, Gottsch JD. Cataract surgery in Fuchs corneal dystrophy. Curr Opin Ophthalmol. 2010;21(1):15-19. doi:10.1097/ICU.0b013e328333e9d6

17. Klein BE, Klein R, Linton KL. Prevalence of age-related lens opacities in a population. The Beaver Dam Eye Study. Ophthalmology. 1992;99(4):546-552. doi:10.1016/S0161-6420(92)31934-7

18. Krachmer JH, Purcell JJ Jr, Young CW, Bucher KD. Corneal endothelial dystrophy. A study of 64 families. Arch Ophthalmol. 1978;96 (11):2036-2039. doi:10.1001/archopht.1978.03910060424004

19. Traish AS, Colby KA. Approaching cataract surgery in patients with fuchs' endothelial dystrophy. Int Ophthalmol Clin. 2010;50(1):1-11. doi:10.1097/IIO.0b013e3181c5728f

20. Ham L, Dapena I, Moutsouris K, et al. Refractive change and stability after Descemet membrane endothelial keratoplasty. Effect of corneal dehydration-induced hyperopic shift on intraocular lens power calculation. J Cataract Refract Surg. 2011;37(8):1455-1464. doi:10.1016/j.jcrs.2011.02.033

21. van Dijk K, Rodriguez-calvo-de-mora M, van Esch H, et al. Twoyear refractive outcomes after descemet membrane endothelial keratoplasty. Cornea. 2016;35(12):1548-1555. doi:10.1097/ ICO.0000000000001022

22. Aristodemou P, Sparrow JM, Kaye S. Evaluating refractive outcomes after cataract surgery. Ophthalmology. 2019;126(1):13-18. doi:10.1016/j.ophtha.2018.07.009

23. See CW, Iftikhar M, Woreta FA. Preoperative evaluation for cataract surgery. Curr Opin Ophthalmol. 2019;30(1):3-8. doi:10.1097/ ICU.0000000000000535

24. Sahin A, Hamrah P. Clinically relevant biometry. Curr Opin Ophthalmol. 2012;23(1):47-53. doi:10.1097/ICU.0b013e32834cd63e

25. Donaldson K, Fernández-Vega-Cueto L, Davidson R, et al.; ASCRS Refractive-Cataract Surgery Subcommittee. Perioperative assessment for refractive cataract surgery. J Cataract Refract Surg. 2018;44 (5):642-653. doi:10.1016/j.jcrs.2018.02.022
26. Alió JL, Abdou AA, Puente AA, Zato MA, Nagy Z. Femtosecond laser cataract surgery: updates on technologies and outcomes. $J$ Refract Surg. 2014;30(6):420-427. doi:10.3928/1081597X20140516-01

27. Agarwal A, Jacob S. Current and effective advantages of femto phacoemulsification. Curr Opin Ophthalmol. 2017;28(1):49-57. doi:10.1097/ICU.0000000000000333

28. Krarup T, Morten Holm L, la Cour M, Kjaerbo H. Endothelial cell loss and refractive predictability in femtosecond laser-assisted cataract surgery compared with conventional cataract surgery. Acta Ophthalmol. 2014;92(7):617-622. doi:10.1111/aos.12406

29. Day AC, Gore DM, Bunce C, Evans JR. Laser-assisted cataract surgery versus standard ultrasound phacoemulsification cataract surgery. Cochrane Database Syst Rev. 2016;8(7):CD010735.

30. Filkorn T, Kovács I, Takács A, Horváth E, Knorz MC, Nagy ZZ. Comparison of IOL power calculation and refractive outcome after laser refractive cataract surgery with a femtosecond laser versus conventional phacoemulsification. $J$ Refract Surg. 2012;28 (8):540-544. doi:10.3928/1081597X-20120703-04

31. Conrad-Hengerer I, Al Sheikh M, Hengerer FH, Schultz T, Dick HB. Comparison of visual recovery and refractive stability between femtosecond laser-assisted cataract surgery and standard phacoemulsification: six-month follow-up. J Cataract Refract Surg. 2015;41 (7):1356-1364. doi:10.1016/j.jcrs.2014.10.044

32. Zhu DC, Shah P, Feuer WJ, Shi W, Koo EH. Outcomes of conventional phacoemulsification versus femtosecond laser-assisted cataract surgery in eyes with Fuchs endothelial corneal dystrophy. $J$ Cataract Refract Surg. 2018;44(5):534-540. doi:10.1016/j.jcrs.2018.03.023

33. Fan W, Yan H, Zhang G. Femtosecond laser-assisted cataract surgery in Fuchs' endothelial corneal dystrophy: long-term outcomes. $J$ Cataract Refract Surg. 2018;44(7):864-870. doi:10.1016/j. jcrs.2018.05.007

34. Yong WWD, Chai HC, Shen L, Manotosh R, Anna Tan WT. Comparing outcomes of phacoemulsification with femtosecond laser-assisted cataract surgery in patients with fuchs endothelial dystrophy. Am J Ophthalmol. 2018;196:173-180. doi:10.1016/j. ajo.2018.08.006

35. Al-Mohtaseb Z, He X, Yesilirmak N, Waren D, Donaldson KE. Comparison of corneal endothelial cell loss between two femtosecond laser platforms and standard phacoemulsification. $J$ Refract Surg. 2017;33(10):708-712. doi:10.3928/1081597X-20170731-01

36. Wacker K, Cavalcante LCB, Baratz KH, Patel SV. Hyperopic trend after cataract surgery in eyes with fuchs' endothelial corneal dystrophy. Ophthalmology. 2018;125(8):1302-1304. doi:10.1016/j. ophtha.2018.03.060

37. Patel SV, Baratz KH. A commentary on the Yong article: comparing outcomes of phacoemulsification with femtosecond laser-assisted cataract surgery in patients with fuchs endothelial dystrophy. Am J Ophthalmol. 2019;199:258-259. doi:10.1016/j. ajo.2018.10.028

38. Hwang RY, Gauthier DJ, Wallace D, Afshari NA. Refractive changes after DSEK: a simplified mathematical model. Invest Ophthalmol Vis Sci. 2011;22(52):1043-1054. doi:10.1167/iovs.10-5839

39. Shajari M, Kolb CM, Mayer WJ, et al. Characteristics of preoperative and postoperative astigmatism in patients having Descemet membrane endothelial keratoplasty. J Cataract Refract Surg. 2019;45 (7):1001-1006. doi:10.1016/j.jcrs.2019.02.002 


\section{Publish your work in this journal}

Clinical Ophthalmology is an international, peer-reviewed journal covering all subspecialties within ophthalmology. Key topics include: Optometry; Visual science; Pharmacology and drug therapy in eye diseases; Basic Sciences; Primary and Secondary eye care; Patient Safety and Quality of Care Improvements. This journal is indexed on PubMed
Central and CAS, and is the official journal of The Society of Clinical Ophthalmology (SCO). The manuscript management system is completely online and includes a very quick and fair peer-review system, which is all easy to use. Visit http://www.dovepress.com/ testimonials.php to read real quotes from published authors. 